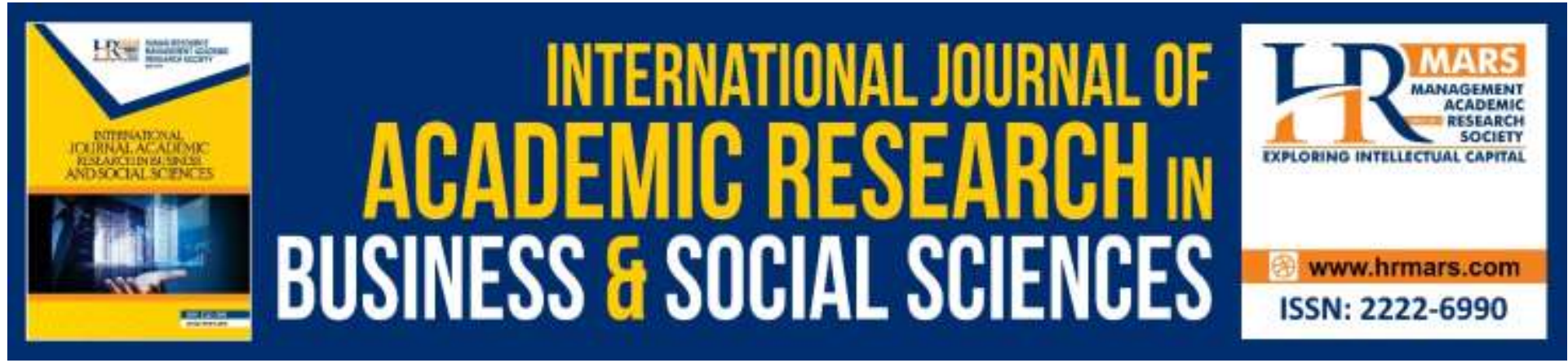

\title{
Development of an Instrument to Evaluate Emotional Intelligence and Leadership Style of Headmasters across Primary Schools in Malaysia
}

Noor Fazilah Ahmad Jamli, Syed Sofian Syed Salim

To Link this Article: http://dx.doi.org/10.6007/IJARBSS/v9-i7/6197 DOI: 10.6007/IJARBSS/v9-i7/6197

Received: 01 May 2019, Revised: 11 June 2019, Accepted: 30 June 2019

Published Online: 07 July 2019

In-Text Citation: (Jamli \& Salim, 2019)

To Cite this Article: Jamli, N. F. A., \& Salim, S. S. S. (2019). Development of an Instrument to Evaluate Emotional Intelligence and Leadership Style of Headmasters across Primary Schools in Malaysia. International Journal of Academic Research in Business and Social Sciences, 9(7), 988-993.

Copyright: (C) 2019 The Author(s)

Published by Human Resource Management Academic Research Society (www.hrmars.com)

This article is published under the Creative Commons Attribution (CC BY 4.0) license. Anyone may reproduce, distribute, translate and create derivative works of this article (for both commercial and non-commercial purposes), subject to full attribution to the original publication and authors. The full terms of this license may be seen

at: http://creativecommons.org/licences/by/4.0/legalcode

\section{Vol. 9, No. 7, 2019, Pg. 988 - 993}

Full Terms \& Conditions of access and use can be found at http://hrmars.com/index.php/pages/detail/publication-ethics 


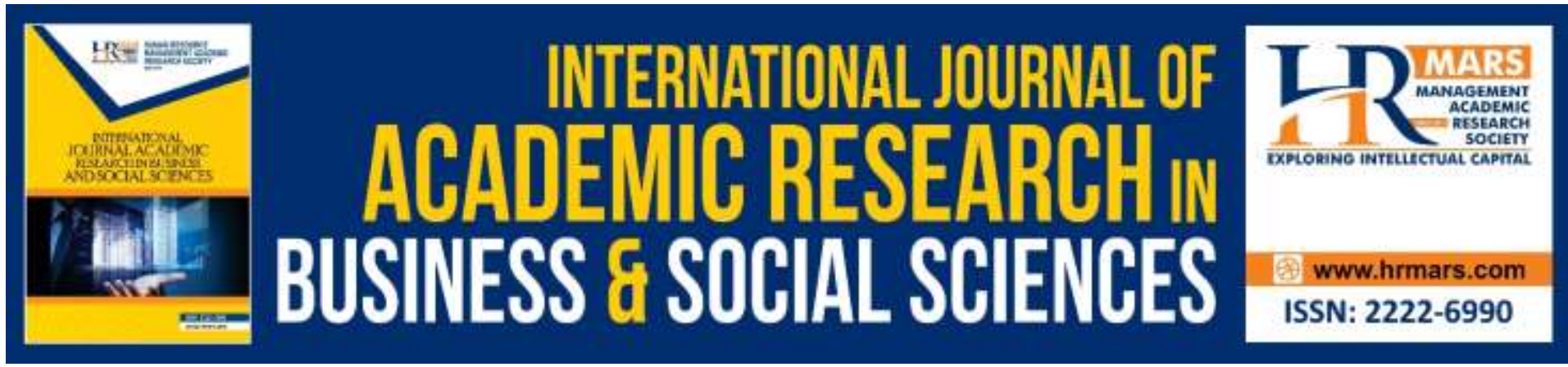

\title{
Development of an Instrument to Evaluate Emotional Intelligence and Leadership Style of Headmasters across Primary Schools in Malaysia
}

\author{
Noor Fazilah Ahmad Jamli, Syed Sofian Syed Salim \\ Faculty of Education and Human Development, Sultan Idris Education University, 35900 \\ Tanjong Malim, Perak \\ Email: aininatashanajwa@gmail.com
}

\begin{abstract}
The aim of this study is developed and validated a questionnaire to measure emotional intelligence and leadership style amongst primary school headmasters across Malaysia. The instrument was designed by adopting several standard procedures, including item development, validation of theoretical construct of Emotional Intelligence and Leadership Style, pilot test, and validation of the developed instrument. The questionnaires were tested among 50 school headmasters within four week timeframe. The pilot study was conducted to validate all the items embedded in the questionnaire. The response rate for the pilot study was $78 \%$. After the pilot study, minor revision and corrections were made to items concerning Emotional Intelligence, while major revision for Leadership Style. The questionnaire consisted of three primary parts: Demographic and School Information, Emotional Intelligence, and Leadership Style. The Cronbach's Alpha values for Emotional Intelligence and Leadership Style are (0.868) and (0.726), respectively.
\end{abstract}

Keywords: Emotional Intelligence, Leadership Style, Instrument, Validity, Reliability

\section{Introduction}

In leadership studies across Western nations, successful leaders in management and leadership aspects are associated with emotional intelligence (Stokely, 2008). Leaders with high emotional intelligence are able to adapt themselves to workplace environments that enable them to manage any conflict (Hopkins \& Yonker, 2015). From the stance of leadership within schools, Williams (2008b) highlighted that the distinguishing factor amidst distinguished school leaders, when compared to ordinary school leaders, is a combination of emotional intelligence and social intelligence, which in turn, can indirectly influence students' achievement (Muijs, 2011).

Goleman, who had looked into emotional intelligence in aspects of behavior and interaction in relationships and work situations, emphasized on the importance of emotional intelligence as a measuring rod in the ability of leaders and subordinates to regulate self-emotions and other aspects in social interactions (Schlosberg, 2006). 


\section{Research Questions}

1. To determine the validity of the instrument that evaluates Emotional Intelligence Assessment and Leadership Style of Headmasters across primary schools in Malaysia.

2. To determine the reliability of the instrument that evaluates Emotional Intelligence Assessment and Leadership Style of Headmasters across primary schools in Malaysia.

\section{Research Methodology}

This study adopted the quantitative study approach to address the research questions and to test the developed hypotheses based on the data retrieved from the quantitative analysis (Edinin, 2012). According to Harwell (2011), a quantitative study involves the use of instruments as the major element of the study. The study design is non-experimental type, which applies the correlation study method. Hence, the researcher assessed the relationships between the variables (Creswell, 2014) by measuring, collecting, and analyzing data in a descriptive manner using SPSS (Statistical Package for the Social Sciences) application. In the data collection process, the researcher employed the questionnaire instrument. The selfdeveloped Emotional Intelligence and Self-Assisted Questionnaire had been employed in this study to identify the level of emotional intelligence and transformative leadership style amongst headmasters of schools selected as the study sample.

\section{Population and Sample of Study}

Determination of sample size is a critical factor in a study (Ismail, 2016). The selected sample size illustrates the overall population of the study. In order to obtain accurate answers, optimally, the sample size should be noted. The population in this study refers to all primary school headmasters under the Malaysian Ministry of Education (KPM). Through the data derived from KPM 2016, it was observed that the population of headmasters is 7769 based on the number of primary schools. Hence, the researcher decided to include 7769 respondents as the study population. In this study, the population size was big and the researcher had to get the sample in a randomly grouped manner. The method of random group is complex, where populations need to be broken down into groups (Olsen, 2012). In this study, the overall sample population was broken down into three zones.

\section{Research Instrument}

The questionnaire instrument is a tool that consists of several sets of questions or items for the purpose of obtaining feedback from the research sample in a standard method (Bhattacherjee, 2012). In this study, a questionnaire instrument was specially constructed by the researcher to obtain data from the research sample. The questionnaire construction process comprised of the following (Talib, 2013): a) understanding the terms used by the researcher, b) questions being understood by all respondents, and c) if questions attract the respondents' interest in responding. The questionnaire instrument in this study was constructed by using a structured item measurement tool. For the selection of item scale, the researcher included Nominal Scale for Part A: Demographic Information, while Ordinal Scale 
for Part B: Emotional Intelligence, and Likert scale for Part C: Leadership Style in order to retrieve responses from the respondents.

\section{Item Construction Procedure}

As for the types of questionnaire items used in light of the quantitative research, closedended questions are often used by researchers to obtain information from the study sample (Dawson, 2002). According to Cohen, Manion, and Morrison (2007), when dealing with a large sample size, it is necessary to use structured questionnaires, closed and numerical questions in simple, clear, and unambiguous questions to facilitate respondents to choose the most appropriate answers (Talib, 2013).

Questionnaire items were built using several construction phases. The first step carried out by the researcher in constructing the questionnaire instrument was to identify the constructs and dimensions based on the underpinning theories applied in this study. The constructs by Goleman Emotional Intelligence Theory (1998) and the Avolio and Bass Transformation Leadership Style Theory (1991) are in accordance with the objectives and questions of this study, which had been sub-divided into each sub-construct to construct items that represent each study dimension (Talib, 2013). Next, the researcher identified the data that had to be obtained in line with the study objectives before the commencement of several phase cycles in designing the items (Wilson, 2013).

\section{Instrument Validation Process}

Ismail (2016) listed three important issues involved in the process of building an instrument, forming a suitable and reliable measurement tool that is broken down into parts, wherein the items should be equal in all subjects to obtain the desired information. Apart from that, the use of language and words should be clear and easy to understand with simple and easy-toread sentence structure. Item formation should be in line with the underpinning theory. The next step was to identify the sub-structures from the study theory. Constructing subconstructs that incorporate concepts related to the study objectives should be operational in order to facilitate numerical analysis.

After the items had been constructed based on the constructs of the research theories, the first model of the questionnaire instrument for the expert review process was constructed so that all items in the research instrument are in accordance with the constructs to be studied. Expert confirmation determines the aspect of construct validation and authentication of content. The validity of the construct refers to the ability of an instrument to accurately measure the proposed constructs in the study theory (Prous, Salvanes, \& Ortells, 2009). For this study, the process of validating the constructs and the content was conducted with the review of the field of Social Psychology, Educational Psychology and Counseling from University Sains Malaysia for the constructs of Emotional Intelligence, while the University Malaysia Sarawak in Cognitive Development, Leadership, and Cognitive Styles for the Headmaster Leadership Style constructs and two field experts Language and Communication UNIMAS for the validation of the language aspect used in each item. Based on feedback and approval in every construct of the questionnaire item, as well as suggestions and improvements from the researcher, the questionnaire was improved in terms of the constructs and arrangement of sentences in each item. 
Upon improvement, the researcher released an initial model of the instrument in a pilot study involving 50 samples to obtain the required research data. The pilot study process determined the relevance of the questionnaire items and the clarity of the language used to coincide with the suitability of respondents. All items in the instrument are in accordance with the respondents' understanding because no respondent gave negative feedback about the items. In order to obtain internal authenticity for the questionnaire instrument, a pilot study was conducted by distributing the questionnaires to 50 research samples from five District Education Offices located in Kuching, Lundu, Padawan, Bau and Serian. The length of time allocated was a week for the questionnaire sending process, and two weeks to gain feedback; between September 24, 2018 and October 14, 2018. The results of Cronbach's Alpha analysis for Emotional Intelligence (40 items) and leadership style (24 items) were 0.868 and 0.726 , respectively.

\section{Conclusion}

This study developed a scale that can be used to measure the aspects of emotional intelligence and leadership style amongst headmasters. From the initial construction of the questionnaire, the Emotional Intelligence construct had 45 items, while 51 items for the Leadership Style construct. However, after undergoing expert review process and item consistency analysis, 4 and 27 items were discarded from the emotional intelligence and leadership style constructs, respectively, as they failed to meet the criteria of consistency.

\section{Corresponding Author}

Syed Sofian Bin Syed Salim

Faculty of Education and Human Development,

Sultan Idris Education University,

35000 Tanjung Malim

Perak, Malaysia.

\section{References}

Bhattacherjee, A. (2012). Social Sciences Research : Principles, Methods and Survey Research Practices.

Cohen, L., Manion, L., \& Morrison, K. (2007). Research Method in Education.

Creswell, J. W. (2014). Research Design Qualitative, Quantitative and Mixed Methods Approaches (4th ed.). SAGE Publications, Inc

Dawson, C. (2002). Practical Research Methods A User Friendly Guide To Mastering Research. How To Books Ltd.

Harwell. (2011) Reseach Design in Qualitative, Quantitative and Mixed Method.

Hopkins, M. M., \& Yonker, R. D. (2015). Managing conflict with emotional intelligence: abilities that make a difference. Journal of Management Development, 34(2), 226-244. http://doi.org/10.1108/JMD-04-2013-0051

Harwell, M. R. (2011). Reseach Design in Qualitative, Quantitative and Mixed Method.

Muijs, D. (2011). Leadership and organisational performance: from research to prescription ?, 25(1), 45-60. http://doi.org/10.1108/09513541111100116

Olsen, W. (2012). Data Collection: Key Debates And Methods In Social Research. SAGE Publications, Inc.

Talib, O. (2013). Asas Penulisan Tesis Penyelidikan \& Statistik (Cetakan Pe). Malaysia, 
Penerbitan Universiti Putra.

Edinin, R. (2012). Penyelidikan Tindakan: Kaedah dan Penulisan (Kedua). Freemind Horizons Sdn. Bhd.

Ismail, R. (2016). Metodologi Penyelidikan: Teori dan Praktis. Universiti Kebangsaan Malaysia. Retrieved from http://www.ukm.edu.my/penerbit

Schlosberg, P. B. (2006). 1 transformational leadership: a holistic view of organizational change. MagPro Publishing.

Stokely, D. R. (2008). A Correlational Study of El and Successful Leadership in the Retail Industry.

Williams, H. W. (2008). Characteristics that distinguish outstanding urban principals: Emotional intelligence, social intelligence and environmental adaptation. Journal of Management Development, 27(1), 36-54. http://doi.org/10.1108/02621710810840758

Wilson, C. (2013). Credible Checklists and Quality Questionnaires Credible Checklists and Quality Questionnaires A User-Centered Design Method. Elsevier.

Prous, Y. M. J. G., Salvanes, F. R., \& Ortells, L. C. (2009). Validation Of Auestionnaires.

Reumatologia Clinica, 5(4), 171-177. Retrieved from www.reumatologiaclinica.org 